\title{
大腿骨近位部骨折における退院時歩行能力に影響する因子の検討
}

\author{
久保 祐 介* 野口康男*力丸俊 一**佛坂 俊 輔* \\ 前隆 男* 佐々木 宏 介* 井口貴 裕* 白木 誠* \\ 永 野 賢* 泉政 寛*
}

\section{Factors Influencing Ambulatory Ability of Surgically Treated Hip Fracture Patients at Discharge from Hospitals}

\author{
Yusuke Kubo*, Yasuo Noguchi*, Shunichi Rikimaru*, Shunsuke Hotokezaka*, \\ Takao Mae*, Kosuke Sasaki*, Takahiro Iguchi*, Makoto Shiraki*, \\ Satoshi Nagano*, and Masahiro Izumi*
}

【目的】大腿骨近位部骨折の退院時の転帰掞よび歩行能力に及ほす受傷前の日常生活動作（ADL）自立 度抢よび認知症の有無の影響を明らかにする。【対象と方法】当院で手術して転院した大腿骨近位部骨折 115 例の転院先退院時の転帰（退院先）扔よび歩行能力と受傷前の ADL 自立度㧍よび認知症の有無の相 関を，地域連携パスのフィードバックデータを用いて検討した。【結果】在宅復帰（自宅 $\rightarrow$ 自宅）率は $73.1 \%$ であった. 施設への退院例は自宅退院例に比し退院時の歩行能力が低い傾向にあった. 受傷前 ADL 自立度と退院時の歩行能力には明らかな相関がみられた。受傷前に独力で外出可能だった患者のうち退院 時に屋外歩行ができている割合は $40.6 \%$ で，認知症があると屋外歩行まで回復する割合が認知症なしに 比較して有意に低かった。【結論】退院時に扔ける歩行能力は転帰に影響し，歩行能力の獲得は受傷前の ADL 自立度と認知症の有無に影響される。

We analyzed the destination at discharge and ambulatory ability at the time of discharge from rehabilitation hospitals of 115 hip fracture patients, who underwent surgical treatment at our hospital, in relation with pre-injury level of activities of daily living (ADL) and dementia, by using feedback data of regional liaison pathway sheets sent from rehabilitation hospitals. Seventy-three percent of the patients who lived at home were discharged back home. Patients who were discharged back to nursing homes had lower ambulatory ability at discharge than those who returned home. An apparent relationship between pre-injury level of ADL and ambulatory ability at discharge was found, and $40 \%$ of patient who could walk by themselves before hip fracture regained outdoor ambulatory ability. Patients with dementia showed lower recovery rate of ambulatory ability than those without. We conclude that ambulatory ability at discharge from rehabilitation hospital is influenced by the discharge destination, i.e., own home or nursing home, and that ambulatory ability at the time of discharge is related to the pre-injury level of ambulatory ability and dementia.

Key words : ambulatory ability (歩行能力), hip fracture (大腿骨近位部骨折), dementia (認知症), regional liaison pathway（地域連携パス）

\section{は じめに}

大腿骨近位部骨折は高齢者に多く，高齢化社会の 進行とともに近年増加傾向にある骨折の一つであり， 当院においても最も多い代表的な疾患となっている. 今世紀に入ってわが国でも病院完結型医療から地域完
結型医療へ移行し，大腿骨近位部骨折でも病病㧍よび 病診連携により手術は急性期病院で行い手術後のリハ ビリテーションは回復期病院へ転院して行うことが多 くなってきた。それに伴い，回復期リハビリテーショ ン（リハ）医療機関からの転帰（退院先）や退院する 時点の歩行能力などの患者状態が見えにくくなってき

\footnotetext{
* 佐賀県立病院好生館整形外科 Department of Orthopedic Surgery, Saga Prefectural Hospital Koseikan, Saga, Japan
} 
表 1 障害高齢者の日常生活自立度判定基準

\begin{tabular}{|c|c|c|}
\hline （障害なし） & 障害がない & \\
\hline J & 独力で外出 & $\begin{array}{l}\text { 障害等があるが，日常生活はほぼ自立し，独力で外出 } \\
\text { 1.交通機関を利用して外出 } \\
\text { 2. 隣近所へなら外出 }\end{array}$ \\
\hline A & 介助で外出 & $\begin{array}{l}\text { 屋内生活は概ね自立しているが, 介助なしには外出しない } \\
\text { 1.介助により外出, 日中はほとんどべッドから離れて外出 } \\
\text { 2. 外出の頻度が少なく, 日中も寝たり起きたりの生活 }\end{array}$ \\
\hline B & 車椅子 & $\begin{array}{l}\text { 屋内生活で介助必要, 日中もベッド上が主体, 座位は保つ } \\
\text { 1. 車椅子に移乗し, 食事・排泄はベッドから離れて行う } \\
\text { 2.介助により車椅子に移乗 }\end{array}$ \\
\hline $\mathrm{C}$ & 寝たきり & $\begin{array}{l}\text { 一日中ベッド上, 排泄・食事·着替えで介助必要 } \\
\text { 1. 自力で寝返りをうつ } \\
\text { 2. 自力では寝返りをうたない }\end{array}$ \\
\hline
\end{tabular}

ていた。

一方，地域医療機関が連携して円滑に治療を継続す るために地域連携クリニカルパス（連携パス）の開発 が大腿骨近位部骨折を中心に2005 年頃から全国各地 で取り組まれ，当院でも 2006 年より大腿骨近位部骨 折の連携パスの運用を開始した。当院から回復期の医 療機関への転院の際に連携パスを用いて患者状態等の さまざまな情報提供を行い，当院と連携している回復 期リハ医療機関（連携医療機関）からの退院時にはそ の時点での患者状態や退院先などの情報を当院へ フィードバックしてもらうようにしている.

今回，連携医療機関からフィードバックされた退院 時の患者情報を分析することにより，手術を行った大 腿骨近位部骨折患者の転帰や歩行能力などの患者状態 を明らかにし，また転帰や退院時の歩行能力にどのよ うな要因が関わっているかを検証した。

\section{対象と方 法}

検討対象症例は当院で手術を施行した大腿骨近位部 骨折 115 例で, 性別は女性 95 例, 男性 20 例であった。 平成 20 年 9 月～平成 22 年 12 月までに当院から連携 医療機関へ転院し，平成 23 年 1 月までに連携医療機 関から退院した際の情報を記載したパスシートの返送 があったものに限定した。受傷時年齢は 57〜100 歳で 平均年齢 82.5 歳であり，骨折部位は頝部 58 例，転子 部 56 例, 転子下 1 例であり, 術式は骨接合が 78 例（早 期荷重開始 59 例，晚期荷重 19 例)，人工骨頭置換術
が37例であった。また，当院での入院期間も含めた 総入院期間は，自宅から自宅に退院となった患者は平 均 88.3 日, 自宅から介護施設に退院した患者は平均 119.2 日，介護施設から同介護施設に退院となった患 者は平均 97.3 日で退院していた。転帰（退院先）, 受 傷前の居住地，受傷前 ADL 自立度，認知症の有無， 退院時歩行能力について相互の関連を検討した.

受傷前 ADL 自立度に関しては介護認定で用いられ る「障害高齢者の日常生活自立度判定基準」を用いた (表 1)。障害がない場合は障害なし，障害はあるが， 日常生活はほぼ自立している場合は J, 屋内生活は自 立しているが外出には介助を要するものを $\mathrm{A}$ ，屋内 生活で介助を要し，主に車いすで生活する場合を $\mathrm{B}$, 寝たきりを Cと分類した。認知症に関しては，改訂 版長谷川式簡易知能評価スケールを用いて 30 点中 20 点以下を認知症ありとした。退院時歩行能力は訓練し ているレベルではなく実際に患者ができている歩行レ ベル（している動作）で評価した，有意差検定には Mann-Whitney のU 検定を用いた.

\section{結果}

1. 受傷時の居住地と転帰（退院先）

連携医療機関からの退院先を受傷時の居住地で比較 検討した（表 2). 受傷時に自宅に住んでいた患者 93 例中 68 例 $(73.1 \%)$ が自宅退院となり，受傷時に 介護施設に住んでいた患者 13 例中 11 例 $(84.6 \%)$ が 同介護施設に退院となっていた。また，受傷時に自宅 
表 2 受傷時の居住地と退院先（転帰）

\begin{tabular}{c|c|c|c|c|c}
\hline \hline \multicolumn{2}{c|}{} & \multicolumn{3}{|c|}{ 退院先 } & \\
\cline { 2 - 6 } \multicolumn{2}{c}{} & 自宅 & 介護施設 & 医療機関 & 計 \\
\hline $\begin{array}{c}\text { 受 } \\
\text { 傷 }\end{array}$ & 自宅 & $68(73.1 \%)$ & $13(13.9 \%)$ & 12 & 93 \\
\cline { 2 - 6 } $\begin{array}{c}\text { 居 } \\
\text { 焦 }\end{array}$ & 介護施設 & 0 & $11(84.6 \%)$ & 2 & 13 \\
\cline { 2 - 6 } & 医療機関 & 4 & 2 & 3 & 9 \\
\hline
\end{tabular}

表 3 退院先と退院時している動作の相関

\begin{tabular}{|c|c|c|c|c|c|c|c|c|c|c|}
\hline & \multicolumn{9}{|c|}{ 退院時している動作 } \\
\hline & & $\begin{array}{l}\text { 屋 } \\
\text { 外 } \\
\text { 行 }\end{array}$ & $\begin{array}{l}\text { 階 } \\
\text { 算 } \\
\text { 降 }\end{array}$ & $\begin{array}{l}\text { 本 } \\
\text { 杖 } \\
\text { 歩 } \\
\text { 行 }\end{array}$ & \begin{tabular}{|l} 
歩 \\
器 \\
歩 \\
行
\end{tabular} & $\begin{array}{l}\text { 平 } \\
\text { 行 } \\
\text { 棒 } \\
\text { 行 }\end{array}$ & $\begin{array}{l}\text { 車 } \\
\text { 椅 } \\
\text { 委 } \\
\text { 移 } \\
\text { 莗 }\end{array}$ & $\begin{array}{l}\text { 端 } \\
\text { 坐 } \\
\text { 位 }\end{array}$ & $\begin{array}{l}\text { ギ } \\
\text { † } \\
\text { ” } \\
\text { シ } \\
\text { N } \\
\text { ” } \\
\text { ト }\end{array}$ & 計 \\
\hline \multirow{4}{*}{$\begin{array}{l}\text { 退 } \\
\text { 院 } \\
\text { 先 }\end{array}$} & 自宅 & 27 & 13 & 11 & 12 & 4 & 1 & 0 & 0 & 68 \\
\hline & 自宅 $\rightarrow$ 施設 & & 2 & 1 & 3 & 2 & 3 & 1 & 1 & 13 \\
\hline & 施設 $\rightarrow$ 施設 & 1 & 2 & 1 & 2 & 0 & 4 & 0 & 1 & 11 \\
\hline & 計 & 28 & 17 & 13 & 17 & 6 & 8 & 1 & 2 & 92 \\
\hline
\end{tabular}

に住んでいて介護施設に退院となったのは 93 例中 13 例 $(13.9 \%)$ であった。自宅から介護施設に退院 となった 13 例の内訳は認知症により自宅での加療が 困難となった症例が 6 例 $(50 \%) ， A D L$ 低下により介 護施設に退院となった症例が 4 例，独居のため自宅で の生活が困難になった症例が 1 例，〈も膜下出血によ る後遺症のため介護施設に退院となった症例が 1 例で あった。

\section{2. 転帰と退院時歩行能力の相関}

退院先が自宅と介護施設とで退院時 ADL がどう相 関するかを検証した（表 3)。自宅退院となった 68 症 例中 27 例 $(39.7 \%)$ が退院時に屋外歩行できており, 杖歩行までできていたのは 51 例 $(75.0 \%)$ であった. それに対して自宅から介護施設に退院となった患 者で杖歩行が行えていたのは 13 例中わずか 3 例 $(23.1 \%)$ ，介護施設から介護施設に退院となった患者 で 11 例中 4 例 $(36.4 \%)$ であった。

3 . 受傷前 ADL と退院時歩行能力の相関

受傷前 ADL と退院時歩行能力との相関を病院への
表 4 受傷前の日常生活自立度と退院時している動作との 相関（病院への再転院例は除く）

\begin{tabular}{|c|c|c|c|c|c|c|c|c|c|c|}
\hline & \multicolumn{9}{|c|}{ 退院時している動作 } \\
\hline & & \begin{tabular}{|l} 
屋 \\
外 \\
歩 \\
行
\end{tabular} & $\begin{array}{l}\text { 階 } \\
\text { 㑇 } \\
\text { 暴 }\end{array}$ & $\begin{array}{l}\text { 本 } \\
\text { 杖 } \\
\text { 歩 } \\
\text { 行 }\end{array}$ & $\begin{array}{l}\text { 歩 } \\
\text { 器 } \\
\text { 歩 } \\
\text { 行 }\end{array}$ & $\begin{array}{l}\text { 平 } \\
\text { 行 } \\
\text { 棒 } \\
\text { 内 } \\
\text { 歩 } \\
\text { 行 }\end{array}$ & $\begin{array}{l}\text { 車 } \\
\text { 椅 } \\
\text { 子 } \\
\text { 移 } \\
\text { 乗 }\end{array}$ & $\begin{array}{l}\text { 端 } \\
\text { 坐 } \\
\text { 位 }\end{array}$ & $\begin{array}{l}\text { ギ } \\
\text { † } \\
\text { } \\
シ 3 \\
\text { N } \\
\text { ト } \\
\text { ト }\end{array}$ & 計 \\
\hline \multirow{5}{*}{$\begin{array}{c}\text { 受 } \\
\text { 傷 } \\
\text { 前 } \\
\text { A } \\
\text { D } \\
\text { L } \\
\text { 自 } \\
\text { 立度 }\end{array}$} & 障害なし & 12 & 3 & 4 & 0 & 0 & 0 & 0 & 0 & 19 \\
\hline & 独力で外出 & 16 & 10 & 9 & 10 & 2 & 3 & 0 & 0 & 50 \\
\hline & 介助で外出 & 0 & 4 & 2 & 6 & 3 & 2 & 0 & 1 & 18 \\
\hline & 車椅子 & 0 & 0 & 0 & 3 & 2 & 3 & 1 & 1 & 10 \\
\hline & 計 & 28 & 17 & 15 & 19 & 7 & 8 & 1 & 2 & 97 \\
\hline
\end{tabular}

再転院例は除外して検討すると，表 4 に示すように退 院時に屋外歩行が可能であったのは全体では 97 例中 28 例（28.9\%）であった。受傷前 ADL 自立度別にみ ていくと，障害なし群では 19 例中 12 例 $(63.2 \%)$, 独力で外出する群（J）では 50 例中 16 例 (32.0\%) であり，独力で外出が可能だった 69 例中 28 例 (40.6\%) が屋外歩行可能となっていた。一方, 介助 で外出する群 (A) や車椅子生活の群 (B) ではいずれ も屋外歩行獲得例はなく，受傷前 ADL が低くなるほ ど退院時歩行能力は低く, 両者には明らかな相関がみ られた。

4. 退院時の屋外歩行能力と認知症との関連性

受傷前に外出できていた症例（ADL 自立度が障害 なしまたはJ）の退院時の歩行能力を認知症の有無別 に表 5 , および表 6 に示す。認知症のない例で屋外歩 行できていたのは障害なし群で 17 例中 12 例 $(70.6 \%)$, 独力で外出できる群 $(\mathrm{J})$ で 22 例中 10 例 (45.5\%) であったのに対し，認知症がある例では障 害なし群で 3 例中 0 例 $(0 \%)$, 独力で外出できる群 
表 5 退院時屋外歩行能力と認知症の相関（受傷時 ADL が障害なしの例）

\begin{tabular}{|c|c|c|c|c|c|c|c|c|}
\hline & \multicolumn{8}{|c|}{ 退院時している動作 } \\
\hline & $\begin{array}{l}\text { 屋 } \\
\text { 外 } \\
\text { 歩 }\end{array}$ & $\begin{array}{l}\text { 階 } \\
\text { 算 } \\
\text { 降 }\end{array}$ & $\begin{array}{l}\text { 本 } \\
\text { 森 } \\
\text { 歩 } \\
\text { 行 }\end{array}$ & $\begin{array}{l}\text { 歩 } \\
\text { 器 } \\
\text { 歩 } \\
\text { 行 }\end{array}$ & $\begin{array}{l}\text { 平 } \\
\text { 行 } \\
\text { 棒 } \\
\text { 肯 } \\
\text { 歩 }\end{array}$ & $\begin{array}{l}\text { 車 } \\
\text { 椅 } \\
\text { 移 } \\
\text { 乗 }\end{array}$ & $\begin{array}{l}\text { 端 } \\
\text { 佳 }\end{array}$ & 計 \\
\hline 認知症なし & $12(70.6 \%)$ & 2 & 3 & 0 & 0 & 0 & 0 & 17 \\
\hline 認知症あり & $0(0 \%)$ & 2 & 1 & 0 & 0 & 0 & 0 & 3 \\
\hline 計 & 12 & 4 & 4 & 0 & 0 & 0 & 0 & 20 \\
\hline
\end{tabular}

表 6 退院時屋外歩行能力と認知症の相関（受傷時 $\mathrm{ADL}$ が独力で外出の例)

\begin{tabular}{|c|c|c|c|c|c|c|c|c|}
\hline & \multicolumn{8}{|c|}{ 退院時している動作 } \\
\hline & 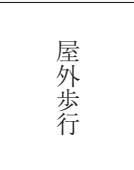 & $\begin{array}{l}\text { 階 } \\
\text { 婜 } \\
\text { 降 }\end{array}$ & $\begin{array}{l}\text { 本 } \\
\text { 森 } \\
\text { 歩 } \\
\text { 行 }\end{array}$ & $\begin{array}{l}\text { 歩 } \\
\text { 器 } \\
\text { 歩 } \\
\text { 行 }\end{array}$ & $\begin{array}{l}\text { 平 } \\
\text { 行 } \\
\text { 棒 } \\
\text { 呙 } \\
\text { 歩 } \\
\text { 行 }\end{array}$ & $\begin{array}{l}\text { 車 } \\
\text { 椅 } \\
\text { 移 } \\
\text { 乗 }\end{array}$ & $\begin{array}{l}\text { 端 } \\
\text { 侳 }\end{array}$ & 計 \\
\hline 認知症なし & $10(45.5 \%)$ & 1 & 4 & 5 & 0 & 2 & 0 & 22 \\
\hline 認知症あり & $6(19.4 \%)$ & 10 & 5 & 6 & 2 & 2 & 0 & 31 \\
\hline 計 & 16 & 11 & 9 & 11 & 2 & 4 & 0 & 53 \\
\hline
\end{tabular}

（J）で 31 例中 6 例 $(19.4 \%)$ が屋外歩行ができてお り, 認知症の有無で有意差を認めた。 $(\mathrm{P}<0.05$ : Mann-Whitney の U 検定)

\section{5. 認知症の有無での患者の歩行能力獲得期間}

歩行能力獲得期間が認知症の有無でどう違うかを, 平行棒歩行訓練開始時期で検討した（表 7)。ここで は歩行開始を一定期間遅らせる晚期荷重の症例は除い て検討した。障害なし群で認知症のない症例は平均 2.85 日, 認知症のある症例で平均 3.33 日, 独力で外 出できる群で認知症のない症例は平均 4.00 日, 認知 症のある症例で平均 4.45 日でそれぞれ平行棒歩行訓 練が開始されていた。

\section{考察}

大腿骨近位部骨折患者では従来当院では転院時の 患者状態の評価しかできなかったが，連携パスの運用 に伴い転院先の退院時の転帰や患者状態などについて フィードバックデータが得られるようになり，治療成 績の集計や検討が容易になってきている，連携パスは 地域完結型医療においてスムーズな医療連携（転院に
表 7 認知症の有無での患者の歩行能力獲得期間

\begin{tabular}{c|c|c}
\hline \hline 受傷前 $\mathrm{ADL}$ & 認知症の有無 & 平行棒歩行開始 \\
\hline \multirow{2}{*}{ 障害なし } & なし $(17$ 例 $)$ & 2.85 日 \\
\cline { 2 - 3 } & あり $(3$ 例 $)$ & 3.33 日 \\
\hline \multirow{2}{*}{ 独力で外出 } & なし(22 例 $)$ & 4.00 日 \\
\cline { 2 - 3 } & あり $(31$ 例 $)$ & 4.45 日 \\
\hline
\end{tabular}

よる治療継続）を可能とする役割を持つが，一方では 治療成績の評価とそれを用いた医療の質の向上にも寄 与することが今回の検討で示唆された。

大腿骨近位部骨折患者における術後の歩行能力獲得 および転帰（退院先）にはさまざまな要因が関わって おり, 今回我々は受傷時の ADL, 認知症の有無, お よび歩行能力獲得期間についての検討を行った。表 3 で示されるように，自宅に居住していて受傷し手術を 受けた患者の約 4 割が退院時に屋外歩行可能となって おり， 4 人に 3 人が杖歩行レベル以上まで歩行能力を 獲得していた。 また, 表 4 で示されるように障害なく 自立していた患者の $63.2 \%$ が屋外歩行能力を再獲得

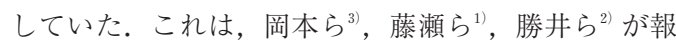
告しているように59～77\% の歩行能力再獲得率と本 研究は同様の結果であった。

また，認知症が大腿骨近位部骨折術後の歩行能力に 最も影響を与える機能予後因子であるという報告は多 数あり，対馬ら ${ }^{4)}$ は HDS-R, CDR，GBS を用いて多 面的精神機能評価と身体機能との影響について述べて いる. 本研究では, 表 5 および表 6 で示したように対 象患者 115 例中 45 例 $(39.1 \%$ ）に認知症を認め，屋 外歩行能力獲得患者数は認知症がなし群とあり群とで 有意に差を認めた。 また，歩行能力獲得期間の検討で は表 7 に示すように有意な差ではないものの, 認知症 がある症例は，ない症例に比べて平行棒歩行訓練の開 始が遅れており，その後の歩行能力獲得に影響してい ることが考えられた。大腿骨近位部骨折は高齢者に多 く，高齢化社会の進行とともに近年増加傾向にある骨 折の一つであり, 術前の認知症の評価および入院中の 進行防止は重要な課題となる。当院では歩行訓練や日 常生活動作の訓練に加えて集団レクレーションも実施 し，それらを午前・午後に分けて実施することで日中 リズムを整えることで ADL 能力の向上はもちろん， リハビリへの意欲向上や認知症悪化防止をはかってい る。 
結

語

1. 大腿骨近位部骨折に対して連携パスを使用するこ とで，連携医療機関に転院した症例の退院時デー タがフィードバックされ，このデータを用いて退 院時の転帰および日常生活動作について検討し た。

2. 受傷時に自宅に住んでいた患者の $73.1 \%$ が自宅 退院となり，障害のなかった患者の $63.2 \%$ ，独 力での外出ができていた患者の $40.6 \%$ が屋外歩 行能力を再獲得していた。
3. 退院時における歩行能力は，受傷前の日常生活自 立度と認知症の有無に影響されることがわかっ た。

\section{参 考 文 献}

1）藤瀬一臣ら：大腿骨転子部骨折の歩行能力の検討．整 外と災外，58(3)：428-431，2009.

2) 勝井龍平, 古田和彦：大腿骨転子部骨折における術後 ADL を決定する因子．骨折，32：114-117，2010.

3）岡本雄策ら：大腿骨頸部骨折の術後歩行能力に影響す る因子の検討. Hip Joint, 34：607-611，2008.

4) 対馬栄輝: 大腿骨近位部骨折の退院時身体機能に対卞 る精神機能の影響. Hip Joint，35：465-470，2009. 